\title{
A Survey on Indian Grapes at Sangli, Maharashtra, India
}

\section{Debjit Ghosh $^{1}$, Chaitali Chakraborty ${ }^{2 *}$ and Riya Dasgupta ${ }^{2}$}

${ }^{1}$ Don-Limon GmbH, Hamburg, Germany

${ }^{2}$ Department of Food Technology, Guru Nanak Institute of Technology, Panihati, Sodepur, Kolkata-114, India

*Corresponding author

\section{A B S T R A C T}

\begin{tabular}{|c|}
\hline Keywords \\
\hline $\begin{array}{l}\text { Grapes, } \\
\text { Export, } \\
\text { Production, } \\
\text { Consumption, } \\
\text { Sangli. }\end{array}$ \\
\hline Article Info \\
\hline $\begin{array}{l}\text { Accepted: } \\
\text { 19 April } 2017 \\
\text { Available Online: } \\
\text { 10 May } 2017\end{array}$ \\
\hline
\end{tabular}

Grapes (Vitis vinifera) are a wonderful subtropical fruit having exceptional pulp content, vibrant color and exert an immense health benefits. It contains considerable amount of phyto-chemicals which reduces the development of chronic diseases. An attempt was made to feed the world by 2050 with best quality Indian grapes. In this study, Sangli scored one of the highest grape producing districts in Maharashtra. Production parameters revealed that $80 \%$ of total production in Maharashtra is exported to European Countries and Canada. In the present study, focus has been given on increasing productivity as well as the tonnages of export of best quality grapes, so that it can play an important role in feeding the world with Indian table grapes according to consumer's demand worldwide by 2050 .

\section{Introduction}

Grapes (Vitis vinifera) are one of the most consumed fruit crop worldwide. India ranks $9^{\text {th }}$ position in grape production (Shikamany, 2001; Gade et al., 2014). The grapes (Vitis vinifera) are one of the most important crops in India. They are generally grown in the subtropical regions of India. Grapes are cultivated in an area of 111.4 thousand hector with a total production 1,234.9 thousand tons in India (Shinde, 2016). 60 percent of total area of Maharashtra is used for grape cultivation. 30 percent of total area in Sangli is under grape cultivation. They can be used in different forms such as raisins, jam, jelly, beverages like juice, wine. Due to its immense potential in improving human's immune system, their demand is increasing day by day throughout the world (Sindhu and Radhai Sri, 2015). Grapes are good source of phyto-chemicals which reduces the risk of chronic diseases, such as certain types of cancer and cardiovascular diseases.

According to, in vitro and in vivo studies grapes have strong antioxidant activity, inhibiting cancer cell proliferation and suppressing platelet aggregation, and also lower down cholesterol. Grapes contain a variety of phyto-chemicals, like phenolic acids, stilbenes, anthocyanins, and proanthocyanidins, all of which act as strong antioxidants (Yang et al., 2013). 


\section{Outlook for grape consumption}

The demand for consumption of table grapes has been increased in last few decades. In U.S., the consumption of table grapes has also been increased from 1970 to 2003. The increased rate of consumption ranges from 2.9 pounds per capita in 1970 to 7.5 pounds in 2003 (Boriss et al., 2006). China's grape consumption has been increased up to 10 percent. It has been surveyed that china's grape consumption is valued for 198 grams per day. Though China is one of the largest grape producing countries, it imports grapes to feed the consumer from other countries (Frederick et al., 2015).

\section{Feed the world by 2050}

The increase in productivity of Indian grapes can feed the world by 2050. In India, Maharashtra is one of the largest grapes producing state with an annual productivity of 774000 tons in 2015. Other major producing states are Karnataka, Tamil Nadu and Andhra Pradesh with an annual production of 330.3, 53 and 27.6 thousand tons respectively. According to a new UN DESA report, it has been revealed that the world population will be reached from 7.3 billion to 8.5 billion by 2030 and to 9.7 billion in 2050 (World Population Prospects: The 2015 Revision). The grape cultivation needs high investment right from the establishment of new vineyard. For successful cultivation of grapes with sustained quality and productivity, a great deal of technical information is needed. Europe consumes table grapes throughout the year. It imports grapes from different countries. But, India exports table grapes in the season Feb-March only which became an important factor. In India, thus, grape sector require more establishment and improvement in the following sectors which includes grape growers, wineries, and supporting industries like cold storages, cool chain transport systems, packaging industry, various input manufacturers and suppliers of agrochemicals, irrigation and trellises systems, local marketers and exporters to fulfill the objective (National Research Centre for Grapes, 2013). The viticulture can be increased by development from ground level. By increasing productivity implementing new technologies for viticulture, vineyard growth and using new growth promoters, world can be fed by 2050 .

\section{Materials and Methods}

Grape production and export from India was started from 1991 with an initiation of economic liberalization. The survey closely observed the condition of grape production and consumption. It has been also checked whether these condition were being helpful to fulfill the objective: Feed the world 2050. The survey on observing several aspects of Indian grapes was carried out at Sangli, Maharashtra. The parameter which was checked at this region based on productivity and quality assessments and how it can be helpful to feed the world by 2050 . The data were statistically analyzed (Snedecor and Cochran, 1967).

\section{Productivity}

The major grape producing countries are China, France, and Italy. The crop ranks fifth in India on the basis of agricultural productivity. $80 \%$ of total production of grapes in India comes from Maharashtra followed by Karnataka and Tamil Nadu. It is mainly grown for wine making, raisin making and for consumption as a fresh table grapes throughout the world. India as well as Maharashtra (Nasik, Sangli, Ahmednagar, Pune, Satara, Solapur and Osmanabad Districts) produces mainly table grapes for consuming as a fresh fruit (National Horticulture Board, 2001-02). Average 
Productivity of these states of the year 201415 is as follows:

a) Maharashtra (774 thousand tons)

b) Karnataka (330.3 thousand tons)

c) Tamil Nadu (53 thousand tons)

d) Andhra Pradesh (27.6 thousand tons)

Sangli is also one of the largest Grape growing regions in Maharashtra. Agricultural activity is one of the most important means at Sangli. Among all the agricultural production, grape production is one of the important activity. The district rank top position in grape cultivation. 30 percent of total area of production is under grape cultivation (Gaikwad, 2005). Area of grape cultivation at Sangli is also increased in last 2 years which has a greater influence in increasing productivity as well as export. During 199596 and 1996-97, area under grapevine cultivation was 4,025 and 4425 hectares respectively with a total production of grapes of 91,980 tons in 1995-96 (Gade and Gaikwad, 2013).Whereas, the productivity increased up to 502.55 tons in 2016-17.

\section{Result and Discussions}

\section{Monthly productivity and export}

The grape season at Sangli, Maharashtra started from January to March. The tonnage of material increases with the seasons goes on. In 2017 the productivity during JanuaryMarch is about 502.54 tons. With respect to productivity, the export material is about $96.65 \%$ of total productivity that is almost equal to 485.54 tons.

\section{Quality assessments}

According to EU standards, the quality parameters such as size, color, sugar and free from diseases and defects are important factors to import the grapes from India and other countries. All these parameters are considered for Thompson seedless and its mutant varieties.

\section{Increased area and productivity}

Area required for grape cultivation has a major influence in productivity. During 201516 , total area of grape production was 38.37 acre with a total productivity of 206.5 tons, whereas it has been increased up to 502.54 tons with a total area of production of 62.24 acre in 2016-2017.

\section{Increased productivity and export}

It was found from gathered data that $70 \%$ of total productivity increases in 2016-17 than the previous few years. As a result of which tonnages of grapes for export has been increased up to $68 \%$. If grape production and export increases at this rate with sustainability in quality parameters, then only India can feed the world by 2050 with best quality table grapes.

\section{Reasons for choice of grape cultivation and export}

The reason for cultivating export quality grapes at sangli was mainly due to availability of favorable climatic condition in this region. The other reasons includes taking from family legacy and for additional source of income. Only one exceptional reason was found for a lady farmer was to be independent as a women. It has been observed that $60 \%$ cultivates and exports grapes because of its favorable climatic condition, $35 \%$ does it because of family legacy (Table 4 and Fig 4).

\section{Waste management}

Waste management of any industry is one of the important steps. For export of table grapes, there is a huge wastage to maintain quality parameters. 
Table.1 Different varieties of grapes available in India

\begin{tabular}{|l|c|c|}
\hline \multicolumn{1}{|c|}{ Varieties } & \multicolumn{2}{c|}{ Characteristics } \\
\cline { 2 - 3 } & \multicolumn{2}{c|}{ Color } \\
\hline Anab-e-Shahi & White & Seeded \\
\hline Bangalore Blue Syn & Black & Seeded \\
\hline Isabella & Black & Seeded \\
\hline Bhokri & White & Seeded \\
\hline Flame Seedless & Red & Seedless \\
\hline Gulabi Syn & Purple & Seeded \\
\hline Muscat Hamburg & Purple & Seedless \\
\hline Perlette & White & Seedless \\
\hline Sharad Seedless - A mutant of Kishmish Chorni & Black & Seedless \\
\hline $\begin{array}{l}\text { Thomson Seedless and its mutants (Tas - A - Ganesh, } \\
\text { Sonaka and Manik Chaman ) }\end{array}$ & White & \\
\hline
\end{tabular}

Source: S.D. Shikhamany, Grape Production in India, 2009

Table.2 Grape Cultivation Crop Concentration Index

\begin{tabular}{|l|l|c|c|}
\hline Sl. No. & Tahsils & $\mathbf{2 0 0 1 - 0 2}$ & $\mathbf{2 0 1 3 - 1 4}$ \\
\hline 1. & Miraj & 1.65 & 2.06 \\
\hline 2. & Palus & N.A. & 2.12 \\
\hline 3. & Tasgaon & 3.03 & 2.67 \\
\hline 4. & Khanapur & 1.67 & 0.63 \\
\hline
\end{tabular}

Source: Gade and Gaikwad, 2013-14

Table.3 Quality Parameters maintained for Export quality grapes at Sangli

\begin{tabular}{|c|c|c|c|}
\hline Country & Size & Sugar & Color \\
\hline European Countries & Minimum $16.5 \mathrm{~mm}$ & Minimum $15.5^{\circ}$ Brix & Fresh White Green \\
\hline Canada & Minimum $17.5 \mathrm{~mm}$ & Minimum $17^{\circ}$ Brix & Fresh White Green \\
\hline
\end{tabular}

Table.4 Farmer's Opinion on reasons for choice of grape cultivation and Export

\begin{tabular}{|l|c|c|c|c|}
\hline \multicolumn{1}{|c|}{ Reasons } & \multicolumn{3}{|c|}{ Opinions (\%) } \\
\hline $\begin{array}{l}\text { Male } \\
\text { Farmers }\end{array}$ & Lady Farmers & Exporters & Others \\
\hline $\begin{array}{l}\text { Availability of } \\
\text { favorable Climatic } \\
\text { Conditions }\end{array}$ & 65.52 & 20.21 & 10.27 & 4 \\
\hline $\begin{array}{l}\text { Taken From Father } \\
\text { Legacy }\end{array}$ & 35 & 0 & 45 & 20 \\
\hline $\begin{array}{l}\text { Additional Source } \\
\text { of Income }\end{array}$ & 55 & 25 & 18 & 2 \\
\hline High yield & 15 & 5 & 75 & 5 \\
\hline Demand for Export & 3 & 1 & 94 & 2 \\
\hline To be independent & 8 & 10 & 80 & 2 \\
\hline
\end{tabular}


Fig.1 Monthly (Jan -Mar, 2017) productivity at Sangli, Maharashtra

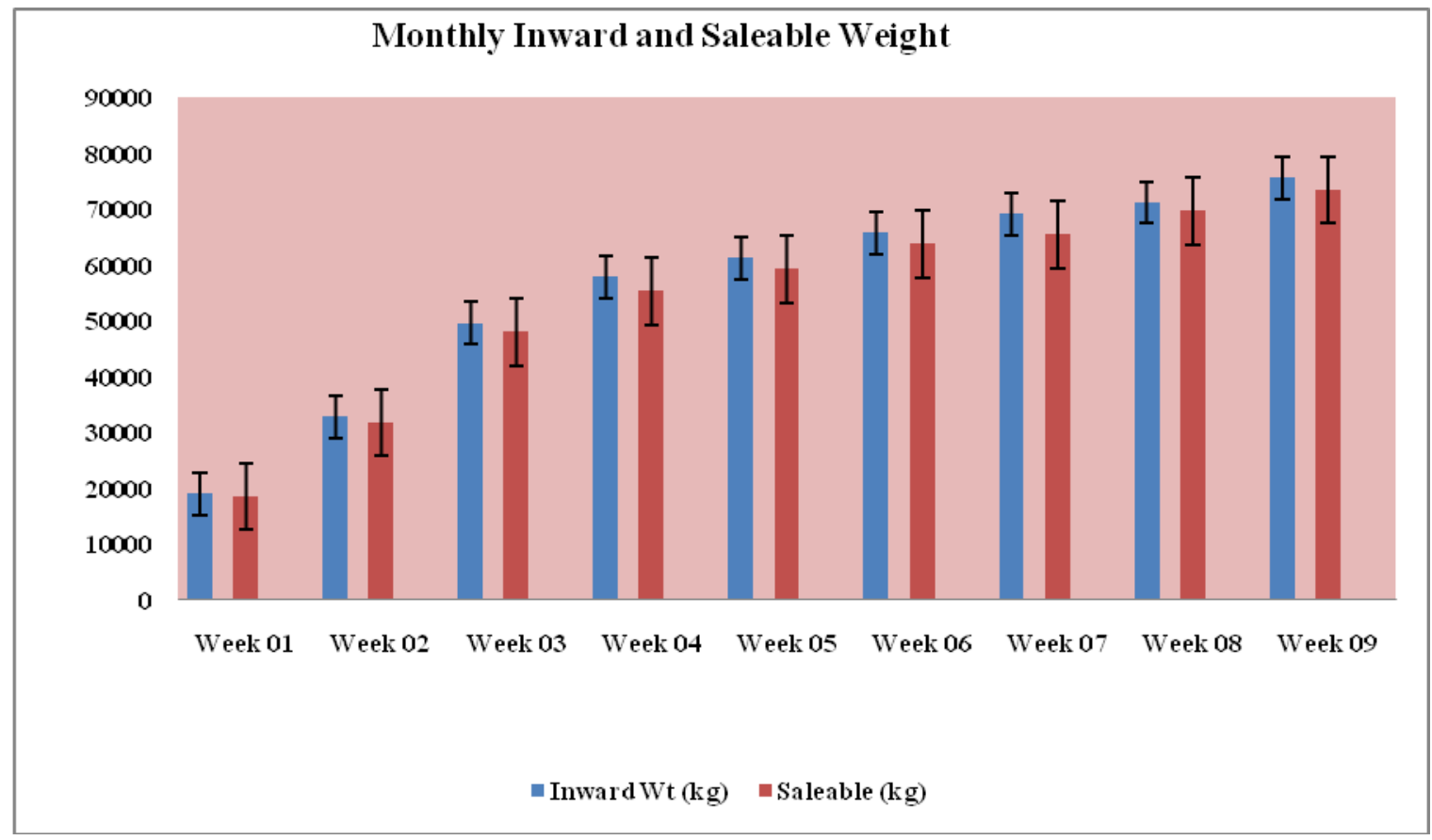

Fig.2 Increased area with increased productivity (2016-17)

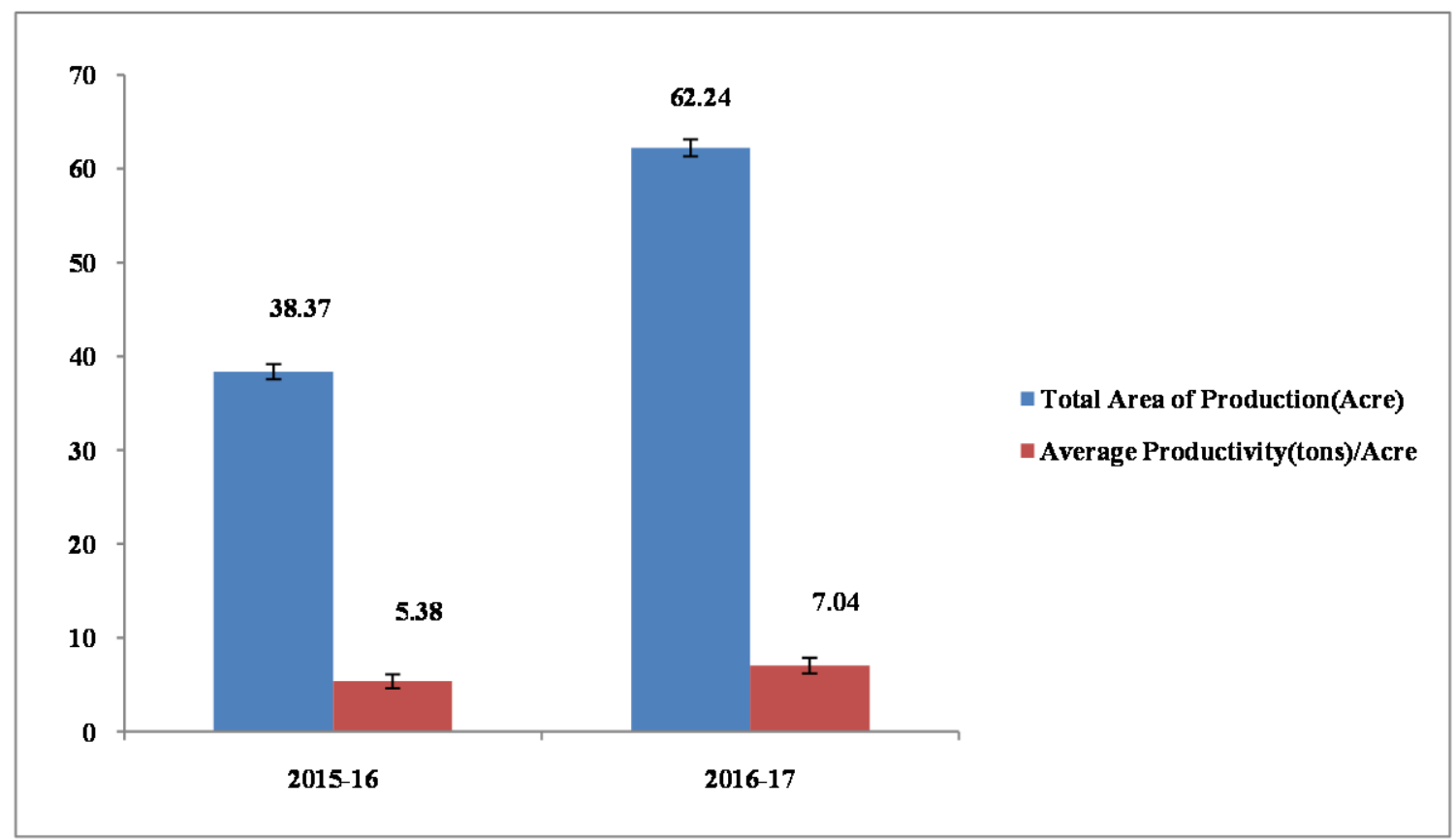


Fig.3 Increased productivity (in tons) and export in 2016-17

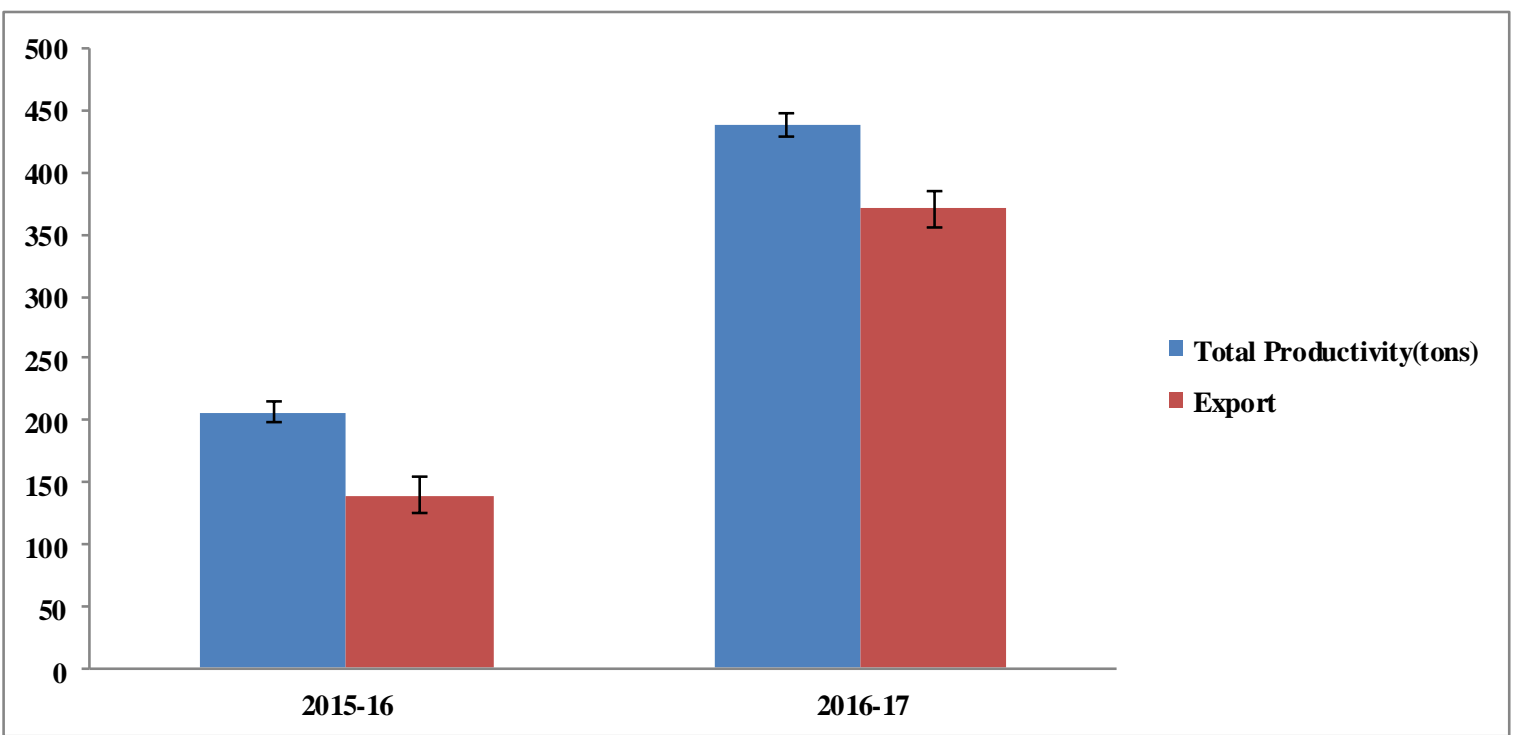

Fig.4 Farmer's opinion on reasons for choice of grape cultivation and export

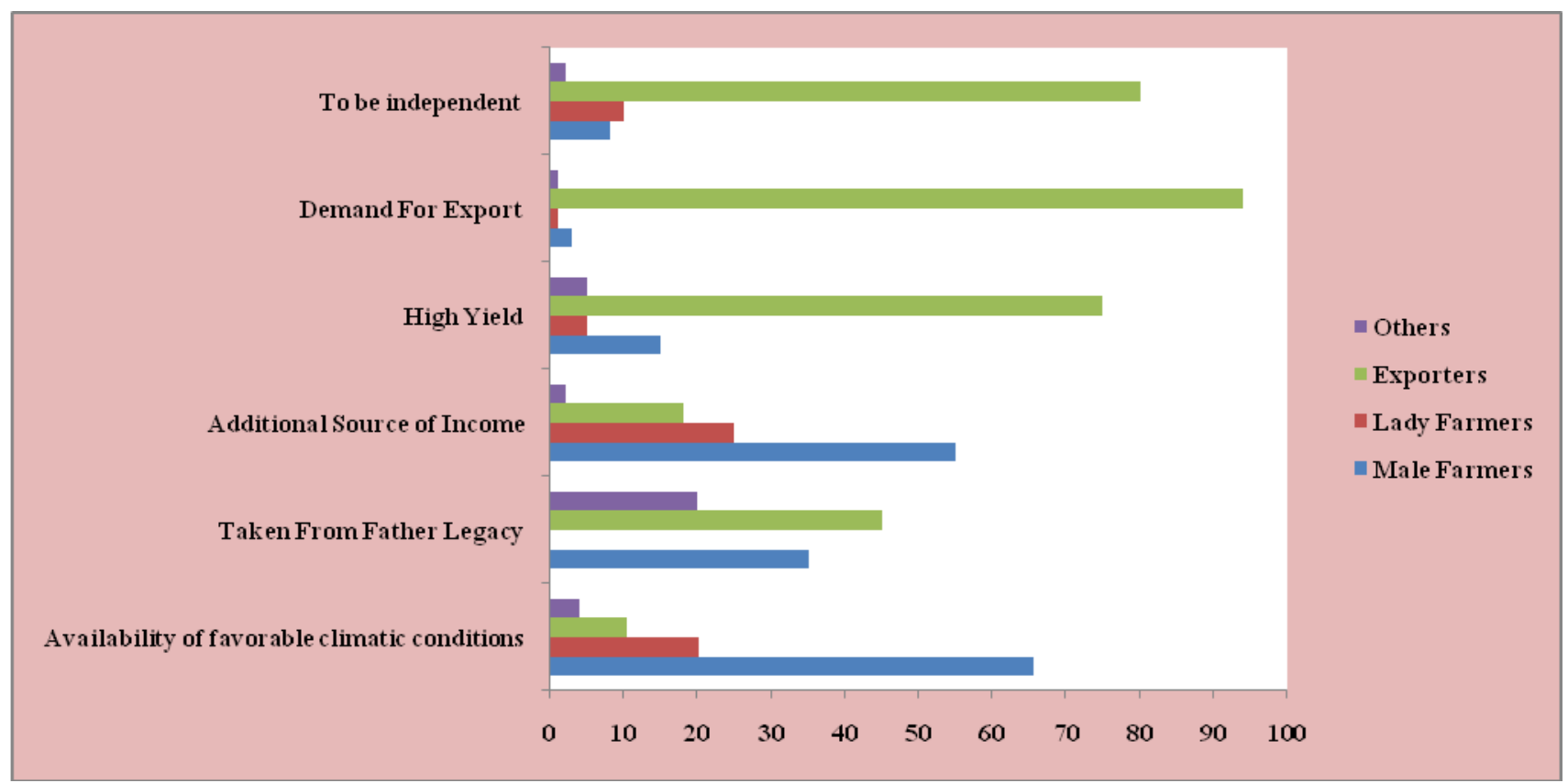


Fig.5 Percentage of wastage at Sangli in Maharashtra during Jan-Mar, 2017

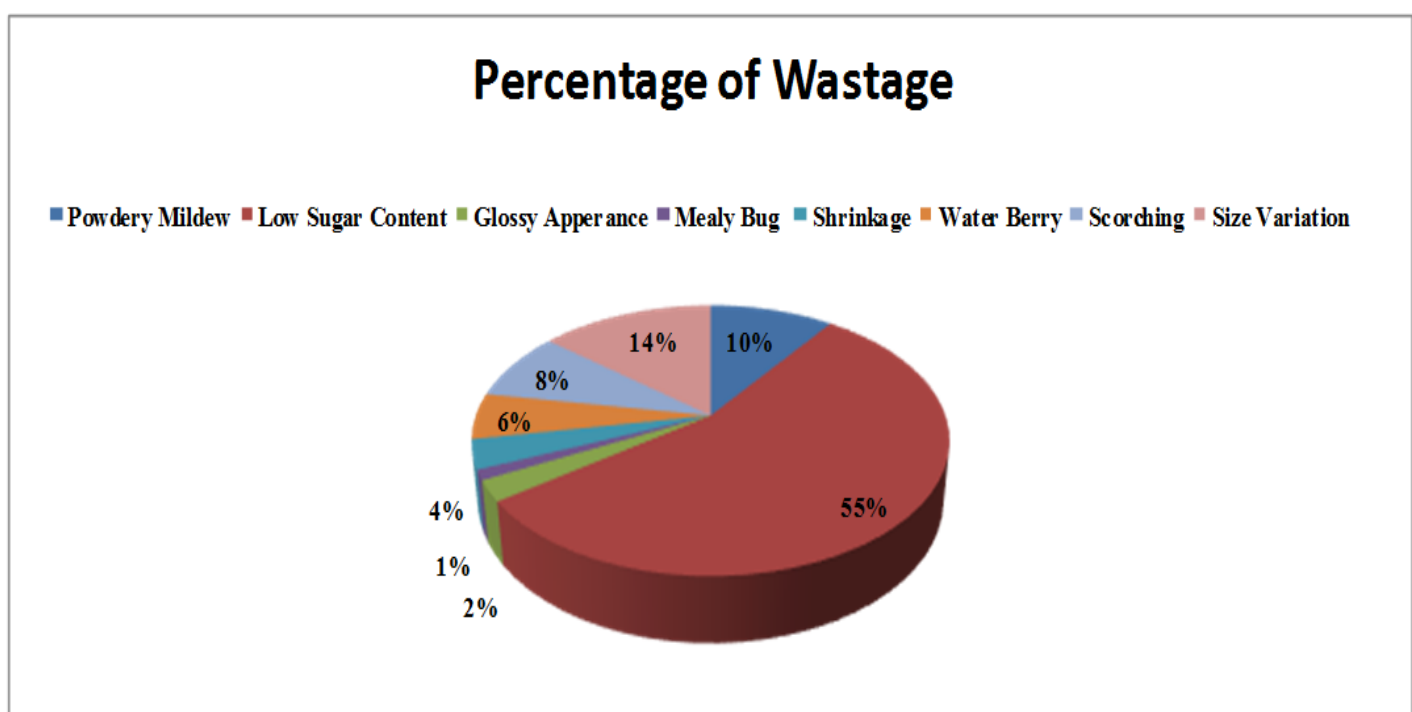

All of the wastage was due to mainly glossy appearance, shrinkage, fungal rotting and defects due to diseases. All of these waste grapes can be classified as per following (Fig. $5)$.

In conclusion, now-a-days, total grape production in India is about 2.58 million MT and per capita availability of 2 kilograms annually.

Now, the growth rate of $4 \%$ if maintained then grapes production will be approximately 9.75 million MT by 2050. Presently, 80 percent of total grapes exported produces in Maharashtra. There is a wide scope of increasing productivity by using new technologies. By doing this, India can feed the world by 2050 . To achieve these targets, a wide range of research work is needed. The complete package of practices including selection of variety and compatible rootstock, vineyard establishment including training systems, variety specific canopy architecture for different end uses such as table grapes, raisin making, or for wine making, use of growth regulators, irrigation and nutrient management, diseases and insect and mite pests management through use of environment friendly chemicals, biopesticides, botanicals has to be developed and should regularly fine tune to comply with domestic and international standards, production of quality grapes with sustainable yields are possible only with these measures.

\section{Future prospects}

India achieves its position for primarily table grapes production. Evaluation of this scenario tells that new researches can develop this field of horticulture. Restoring the germplasm for future development is one of the important steps to feed the world by 2050 . The Grape is one of the first commercially cultivated fruit crop and its cultivation has developed into science by itself. Many new developed varieties shelf -life has been extended up to 6-9 months in cold storage. During raining heavy yield losses occur due to flower drop or bunch rots in cultivated clones of Thompson Seedless and Sharad Seedless. 2A clone of Thompson Seedless do not suffer losses under such situations. Protected cultivation of grapes by plastic bags in Spain and Italy is used. Improvising such new technologies, can only make this goal complete. 


\section{Acknowledgment}

We the authors are hereby acknowledging Don-Limon GmbH, Hamburg, Germany and Agrion Overseas Private Limited, Sangli, Maharashtra, India for giving us opportunity to do the survey on Indian Grape production.

\section{References}

Boriss H., Brunke H., Kreith M.(2006). Commodity Profile: Table Grapes, Agricultural Issues Center, University of California.

ESA (2015). World Population Prospects The 2015 Revision. ESA/P/WP.241. United Nations New York, 2015

rederick C., Liu M., Bugang W. ( 2015). China - Peoples Republic of Fresh Deciduous Fruit Annual.

Gaikwad S.D. (2005): "Grapevine cultivation in Sangli district of Maharashtra: A Geographical Analysis" unpublished Ph.D thesis submitted to Shivaji University, Kolhapur.

Gade A. D, Gaikwad S. B. (2014). Pattern Of Grape Concentration in Sangli district of Maharashtra International Interdisciplinary Research. Journal, pp 157-164.

Gade A. D, Gaikwad S. B., Gaikwad N. S. (2014):Trends in production and exports of grapes in India, Indian Streams Research Journal, 4(2):1-5.
GRAPE: Post Harvest Operations", FAO, 2005

Karande, A.S.(2015) "Bio-dynamic Technology in Organic Farming" Published in Research Front, 1:92-97

Sawant S.D., Upadhyay A., Sawant I.S., Satisha J., Yadav D.S., Annual Report (2013-14) National Research Centre for Grapes,Pune, pp 1-104.

Shikamany S.D. (2001): Grape production in India. In: Papademetrion MK, Dent FJ(eds) Grape production in the asia pacific region,FAO RAP Publ, Bankok, Thailand, pp 15-25.

Shinde P.V. (2016). An Economics of Grapes under Horticulture in India,IJRSI, 3(2):69-71.

Sindhu S., Radhai Sri, S. (2015). Versatile Health Benefits of Active Components of Grapes (Vitis Vinifera), Indian Journal of Applied Research, 5(4):289291.

Shanmugavelue K.G. (1989): Post harvest handling and marketing of grapes. Vitic India, pp- 390.

Snedecor GW, Cochran WG. Statistical Methods. Oxford and IBH Publ Co, Calcutta, India, 1967.

Yang J., Martinson T. E., Liu R. H. (2009). Phyto-chemical profiles and antioxidant activities of wine grapes. Food Chem., 116: 332-339.

\section{How to cite this article:}

Debjit Ghosh, Chaitali Chakraborty and Riya Dasgupta. 2017. A Survey on Indian Grapes at Sangli, Maharashtra. Int.J.Curr.Microbiol.App.Sci. 6(5): 1904-1911. doi: https://doi.org/10.20546/ijcmas.2017.605.211 